\title{
Ice-core evidence of the thickness and character of clear- facies basal ice: Glacier de Tsanfleuron, Switzerland
}

\author{
Bryn Hubbard, ${ }^{1}$ Jean-Louis Tison, ${ }^{2}$ Laurent Janssens, ${ }^{2}$ Barugh Spiro ${ }^{3}$ \\ ${ }^{1}$ Centre for Glaciology, Institute of Geography and Earth Sciences, University of Wales, Aberystwyth, Ceredigion Sr23 3DB, Wales \\ ${ }^{2}$ Département des Sciences de la Terre et de l'Environnement, Faculté des Sciences, \\ CP 160/03 Université Libre de Bruxelles, B-1050 Brussels, Belgium \\ ${ }^{3}$ Natural Environment Research Council Isotope Geosciences Laboratory, Kingsley Dunham Centre, Keyworth, \\ Nottingham, Nottinghamshire NG12 5GG, England
}

\begin{abstract}
Five ice cores have been retrieved from a transect close to the terminus of Glacier de Tsanfleuron, Switzerland. The cores extend from the ice surface to the glacier bed, and are 3.5-44.8 m long. Stratigraphic logging based on bubble size and density reveals the presence of a highly metamorphosed basal ice layer, about $10 \mathrm{~m}$ thick, from which all traces of bubble-rich ice have been removed. This bubble-poor ice, which corresponds closely with clear-facies ice observed in cavities beneath numerous temperate-based glaciers, contrasts with the overlying bubble-rich or bubble-foliated englacial ice and the underlying debris-rich and bubble-free dispersed-facies basal ice.

Down-core patterns in major-ion composition, stable-isotope composition and total gas content and composition are generally consistent with formation of clear-facies ice by deformation-related metamorphism of bubbly, englacial ice. In addition, isotopic data suggest that storage of downward-percolating meltwaters occurs close to the upper surface of the clear-facies ice layer, perhaps reflecting a local variation in ice permeability across the transition from englacial to clear-facies ice. Enrichment in crustally derived ionic species is noted in the lowermost decimetres of the debris-free, clear-facies ice that immediately overlies debris-rich dispersed-facies basal ice. This ionic enrichment in debris-free ice is interpreted in terms of active inter-granular meltwater flow within some decimetres of the glacier bed.
\end{abstract}

\section{INTRODUCTION}

Investigations in cavities beneath predominantly warmbased Alpine glaciers reveal the widespread presence of a massive ice layer that contrasts strongly with underlying, debris-rich basal ice and overlying, bubble-foliated ice, herein referred to as englacial ice (e.g. Vivian and Bocquet, 1973; Vallon and others, 1976; Theakstone, 1979; Hubbard and Sharp, 1995; Jansson and others, 1996). This clear-facies ice is reported to be decimetres to metres thick, and typically contains debris and solute concentrations that are intermediate between those of (debris-rich and solute-rich) basal ice facies and (debris-poor and solute-poor) englacial ice. Theoretical and laboratory-based studies have associated the generation of similar, bubble-poor ice layers with strain-induced pressure melting within initially bubble-rich ice. For example, Brepson (1979) simulated temperate ice flow over a wavy bed in the laboratory through the use of a rotating chamber. One consequence of such flow was the formation of a bubblefree ice layer at locations of enhanced stress at the base of the rotating ice sample. Significantly, this clear-ice layer was not considered to have been formed by refreezing. Barnes and Tabor (1966) observed the formation of a visually similar bubble-free layer following the indentation of temperate ice with hard tools. The layer, which formed to a thickness of $\sim 10 \mathrm{~mm}$ at an ice temperature of $-0.2^{\circ} \mathrm{C}$, was interpreted by these authors in terms of internal stress-induced melting and incomplete refreezing. Robin (1976) argued that such a process may be common beneath temperate glaciers as they slide over rough, rigid substrates, a prediction later supported by modelled temperature and stress fields at the bases of such glaciers (Lliboutry, 1993). According to Lliboutry (1993), local melting occurs within a basal ice layer some tens of $\mathrm{mm}$ thick and the resulting meltwaters flow, through the inter-granular vein network, to areas of lower hydraulic potential, either within the basal ice or at the bed.

Such a process of ice metamorphism may have the capacity to transfer water-borne materials, including dissolved elements, ions, gas and perhaps fine debris, from the lowermost zone of the glacier to the bed. Further, since the rheology of ice depends on its precise physical composition (e.g. Hooke and others, 1988), the presence of physically distinctive, metamorphosed ice close to the glacier bed may have implications for glacier motion. Indeed, many of the physical characteristics that may distinguish clear-facies ice from englacial ice are believed to influence ice rheology. These include ice crystal size and orientation (Hambrey and Milnes, 1975; Baker, 1978; Russell-Head and Budd, 1979), ice ionic chemistry (Nakamura and Jones, 1973) and the amount and composition of water included within the ice (Duval, 1977).

The formation and presence of clear-facies ice in a glacier is therefore of potential significance to net patterns of ice deformation and subglacial weathering (through the delivery of gas, particularly $\mathrm{CO}_{2}$, to the basal interface during clear-facies ice formation). Further, if the origin of clear- 
facies ice can be determined, then physical conditions in the relatively inaccessible interior of an ice mass may be inferred from down-glacier observations of the facies. Despite this potential, however, we still know relatively little about the extent, thickness and detailed physical characteristics of clear-facies ice. In order to address these issues, we have recovered five ice cores from the ablation area of Glacier de Tsanfleuron, Switzerland. Herein, we report on the stratigraphy of these cores, using a visually based classification scheme, and on the physical characteristics of the ice types thereby identified.

\section{FIELD SITE AND METHODS}

Fieldwork was conducted on Glacier de Tsanfleuron, a $\sim 4 \mathrm{~km}^{2}$ plateau glacier located between $\sim 2420$ and $\sim 2850$ $\mathrm{m}$ a.s.l., that flows over Cretaceous and Tertiary limestones (Fig. 1). The glacier has been extensively studied, with the principal focus on the relationship between its basal ice layers (Tison and Lorrain, 1987; Hubbard and Sharp, 1995) and carbonate crusts that have been precipitated on proglacial bedrock surfaces exposed by the retreat of the glacier since the Little Ice Age (Hallet and others, 1978; Lemmens and others, 1983; Souchez and Lemmens, 1985; Sharp and others, 1990; Hubbard and Hubbard, 1998). Hubbard and Sharp (1995) studied the basal ice of the glacier at marginal exposures and in subglacial cavities. Two distinctive basal facies were identified: clear and dispersed. The former occurs as a massive layer that is "devoid of internal layering and contains dispersed debris 'smears' (mean debris concentration = $4.1 \mathrm{~g} \mathrm{~L}^{-1}$ ) and occasional clouds of deformed or flattened bubbles that can give the ice a translucent appearance" (Hubbard and Sharp, 1995, p. 303). The facies was observed to reach a thickness of several metres, and was either in direct contact with the glacier bed or overlay a layer of debris-rich, dispersed-facies basal ice. Analysis of a small number of samples recovered from basal cavities indicated that the clear-facies ice was isotopically heavier than the overlying englacial ice. Together, these characteristics were considered by the authors to be consistent with an origin for clear-facies ice involving strain-induced metamorphism of initially bubble-rich englacial ice close to the glacier bed.

The dispersed-facies ice, which contrasts with that of Lawson's (1979) classification (based on work at Matanuska Glacier, Alaska), "is generally bubble-free and contains coarse-grained debris (mean size $=0.6 \mathrm{~mm}$ ) that is dispersed throughout the ice in crude layers defined by variations in concentration (mean $=47 \mathrm{~g} \mathrm{~L}^{-1}$ ). This debris is frequently polymodal, consisting of silt- through gravelsized clasts" (Hubbard and Sharp, 1995, p. 306). The facies was isotopically heavier than samples of "unaltered" englacial ice and of snow from the glacier surface. These characteristics led Hubbard and Sharp (1995) to argue that dispersed-facies basal ice formed by open-system refreezing of basal waters, requiring a spatially extensive meltwater supply and heat sink. These requirements were consistent with initial formation by freezing within basal cavities, where Tison and Lorrain (1987) had earlier observed the tectonic incorporation of floor-ice layers into the glacier sole. Dispersed-facies ice was therefore interpreted by Hubbard and Sharp (1995) as being formed by the tectonic incorporation and redistribution of floor ice in basal cavities which are common close to the margins of the glacier.

\section{Drilling and ice-core treatment}

Ice cores were recovered using an adapted RAND corer, powered by a portable generator (Tison and others, 1997). Individual core segments, which were typically $75 \mathrm{~mm}$ in diameter and $0.25-0.4 \mathrm{~m}$ long, were logged, bagged and stored on site in a freezer maintained at $\sim-30^{\circ} \mathrm{C}$. The core remained in these freezers during transport from the Alps and during storage until the ice was analyzed in a cold laboratory at $\sim-18^{\circ} \mathrm{C}$. Once in the cold laboratory, ice was logged and sampled using a stainless-steel band-saw. Ice was handled at all times with non-contaminating plastic gloves.

\section{Ice classification}

Ice cores were visually logged in transmitted light and classified at a length resolution of $10 \mathrm{~mm}$ in two stages. First, bubble density and size were recorded on scales of 0-3 (bubble-free to bubble-rich) and 1-3 (small bubbles to large bubbles), respectively (Table 1). For example, ice containing a high density of small bubbles was logged as 3/1, and bubblefree ice as 0 . Secondly, ice was classified into a variety of types defined on the basis of a progression of forms designed to reveal the generation and presence of clear-facies ice in the cores (Table 2). Thus, type 1 ice is characterised by a medium or high density of small bubbles or the fine-scale intercalation of such ice with thin $(\leq 60 \mathrm{~mm})$ layers or lenses of any other ice type. Such foliation is typical of englacial ice formed by firnification, where relatively bubble-poor, blue ice layers alternate at a scale of $\mathrm{cm}$ with relatively bubble-rich, white ice layers (e.g. Hambrey, 1975; Hambrey and Milnes, 1977). The origins of these and other bubble-poor ice types are investigated further below. Ice types $2-5$ are characterised by progressively lower densities of larger bubbles, while ice type 6 is bubble-free and ice type 7 is both bubble-free and debris-rich. All $90.41 \mathrm{~m}$ of core recovered fell into one of these seven ice-type categories.

Table 1. Bubble-density and-size classification

\begin{tabular}{lclc}
\hline Bubble density & Score & $\begin{array}{c}\text { Bubble size } \\
\text { (diameterin mm) }\end{array}$ & Score \\
\hline Bubble-free & 0 & Small $(<1)$ & 1 \\
Low & 1 & Medium $(1-5)$ & 2 \\
Medium & 2 & Large $(>5)$ & 3 \\
High & 3 & & \\
\hline
\end{tabular}

Table 2. Ice-type classification adopted in the study

\begin{tabular}{|c|c|c|c|}
\hline $\begin{array}{l}\text { Ice } \\
\text { type }\end{array}$ & $\begin{array}{l}\text { Bubble- } \\
\text { density } \\
\text { score }\end{array}$ & $\begin{array}{l}\text { Bubble- } \\
\text { size } \\
\text { score }\end{array}$ & Description \\
\hline 1 & $>1$ & $<2$ & $\begin{array}{l}\text { Medium or high density of small bubbles or } \\
\text { the intercalation of such ice with thin } \\
(\leqslant 60 \mathrm{~mm}) \text { layers of any other ice type }\end{array}$ \\
\hline 2 & $>1$ & $=2$ & Medium or high density of medium bubbles \\
\hline 3 & $\leqslant 2$ & $=2$ & Low density of medium bubbles \\
\hline 4 & $\geqslant 2$ & $>2$ & Medium/high density of large bubbles \\
\hline 5 & $<2$ & $>2$ & Low density of large bubbles \\
\hline 6 & $=0$ & & Bubble-free and debris-poor \\
\hline 7 & $=0$ & & Bubble-free and debris-rich \\
\hline
\end{tabular}

Note: Bubble-density and -size s cores are described in Table 1 and in the text. 


\section{Ice characteristics}

Major-ion concentration

Analysis of ionic concentrations was conducted on samples recovered from $\sim 40 \mathrm{~mm}$ lengths of (half-diameter) core. Core samples were melted at room temperature in sealed, pre-washed polyethylene tubs and immediately vacuumdrawn through $0.45 \mu \mathrm{m}$ cellulose nitrate filters prior to bottling, excluding air bubbles, in pre-washed polyethylene bottles. Bottles were kept in dark, refrigerated conditions until analyzed for $\mathrm{Na}^{+}, \mathrm{K}^{+}, \mathrm{Ca}^{2+}, \mathrm{Mg}^{2+}, \mathrm{NO}_{3}{ }^{2-}, \mathrm{Cl}^{-}$and $\mathrm{SO}_{4}{ }^{2-}$ concentrations by ion chromatography (Dionex DX-100). Analytical precision is typically $\pm 5 \%$ at concentrations of $>50 \mu \mathrm{eq} \mathrm{L}{ }^{-1}, \pm 30 \%$ at concentrations of $<10 \mu \mathrm{eq} \mathrm{L} L^{-1}$ and on the order of $\pm 100 \%$ at concentrations of $\sim 1 \mu \mathrm{eq} \mathrm{L} \mathrm{L}^{-1}$ (Tranter and others, 1997). One standard or blank sample was analyzed for every five ice-core samples in order to check instrument stability, which remained within these limits throughout. $\mathrm{HCO}_{3}{ }^{-}$concentrations were determined by charge balance under the assumption that no unconstrained major-ionic species were present in the ice. Charge-balance calculations by Fairchild and others (1994) on the ionic composition of ice and of water recovered from the same glacier indicated errors of $<3 \%$ using this technique. In contrast to their study, however, we measured neither $\mathrm{H}^{+}$nor $\mathrm{Sr}^{2+}$ on our ice-core samples. According to Fairchild and others (1994), the mean $\mathrm{pH}$ of ice-sample groups from the glacier is 7.1-8.7. The corresponding concentration of $\mathrm{H}^{+}$is $<0.1 \mu \mathrm{eq} \mathrm{L}^{-1}$ even at the top end of this range. Similarly, Fairchild and others (1994) measured $\mathrm{Sr}^{+}{ }^{+}$concentrations at the glacier which varied from $0.3 \mu \mathrm{eq} \mathrm{L}{ }^{-1}$ (debris-free ice) to $5.6 \mu \mathrm{eq} \mathrm{L}{ }^{-1}$ (debris-rich basal ice). These values contrast with total cationic concentrations measured at the glacier of 50$830 \mu \mathrm{eq} \mathrm{L}^{-1}$. Thus, concentrations of $\mathrm{H}^{+}$and $\mathrm{Sr}^{2+}$ are minor relative to the total cationic composition of ice at Glacier de Tsanfleuron, suggesting that our charge-balance calculations of $\mathrm{HCO}_{3}{ }^{-}$are within $\pm 10 \%$.

\section{Stable-isotope composition}

Isotopic analysis for oxygen and hydrogen was conducted at the Natural Environment Research Council (NERG) Isotope Geosciences Laboratory, Keyworth, U.K., to an accuracy of $\pm 0.1 \%$ in $\delta^{18} \mathrm{O}$ and $\pm 0.5 \%$ in $\delta \mathrm{D}$.

Gas content and composition

Total gas content was determined by means of extraction by
Toepler pump, following melting and refreezing, as described by Raynaud and Lebel (1979). Total gas contents of $<0.005 \mathrm{~mL}$ $g_{\text {ice }}{ }^{-1}$ fell below the detection limit of the technique. Gas composition was determined by chromatography following dry extraction in a cold room at $-18^{\circ} \mathrm{C}$. Measurement precision is $\pm 2 \%$ for total gas content, $\pm 2.5 \%$ for $\mathrm{CO}_{2}$ concentration and $\pm 4 \%$ for $\mathrm{O}_{2}$ and $\mathrm{N}_{2}$ concentrations (Souchez and others, 1993).

\section{RESULTS}

\section{Ice cores and ice types}

Five ice cores, each extending from the ice surface to the underlying bedrock, were recovered along an approximate flowline extending away from the terminus of the glacier (Fig. 1). Details of core length and stratigraphy are given in Table 3 and Figure 2. The most notable feature of the logs presented in Figure 2 is the presence of a relatively constant thickness of ice types 4-7 at the base of each of the cores. This layer is exposed at the glacier surface in cores 1 and 2 and underlies ice types $1-3$ in the longer cores $3-5$. On the basis of this division, we classify each core into an upper zone (UZ), a lower zone (LZ) and a basal zone (BZ). The boundary between the $\mathrm{UZ}$ and the $\mathrm{LZ}$ is defined as the lowest location of type 1 ice in each core, and the boundary between the $\mathrm{LZ}$ and the BZ is defined as the highest location of debrisrich basal ice (type 7) in each core. Our definition of the LZ, therefore, is that it is debris-poor and devoid of all remnants of bubbly white ice (or ice characterised by a high density of small bubbles). In the field, its blue colour contrasts strongly with the overlying, white $\mathrm{UZ}$ ice. In reality, the LZ is mainly

Table 3. UZ, LZ and BZice thickness in each core (zones are defined in the text)

Core No. Corelength UZdepth LZdepth LZthickness BZthickness

$\mathrm{m}$

$\mathrm{m}$

$\mathrm{m}$

$\mathrm{m}$

$\mathrm{m}$

\begin{tabular}{rrccrl}
\hline 1 & 3.47 & - & $0-3.18$ & $>3.47$ & 0.29 \\
2 & 9.70 & - & $0-9.22$ & $>9.70$ & 0.48 \\
3 & 13.00 & $0-5.18$ & $5.18-12.54$ & 7.82 & 0.46 \\
4 & 19.40 & $0-9.18$ & $9.18-18.45$ & 10.22 & 0.95 \\
5 & 44.84 & $0-30.79$ & $30.79-44.41$ & 14.05 & 0.43
\end{tabular}

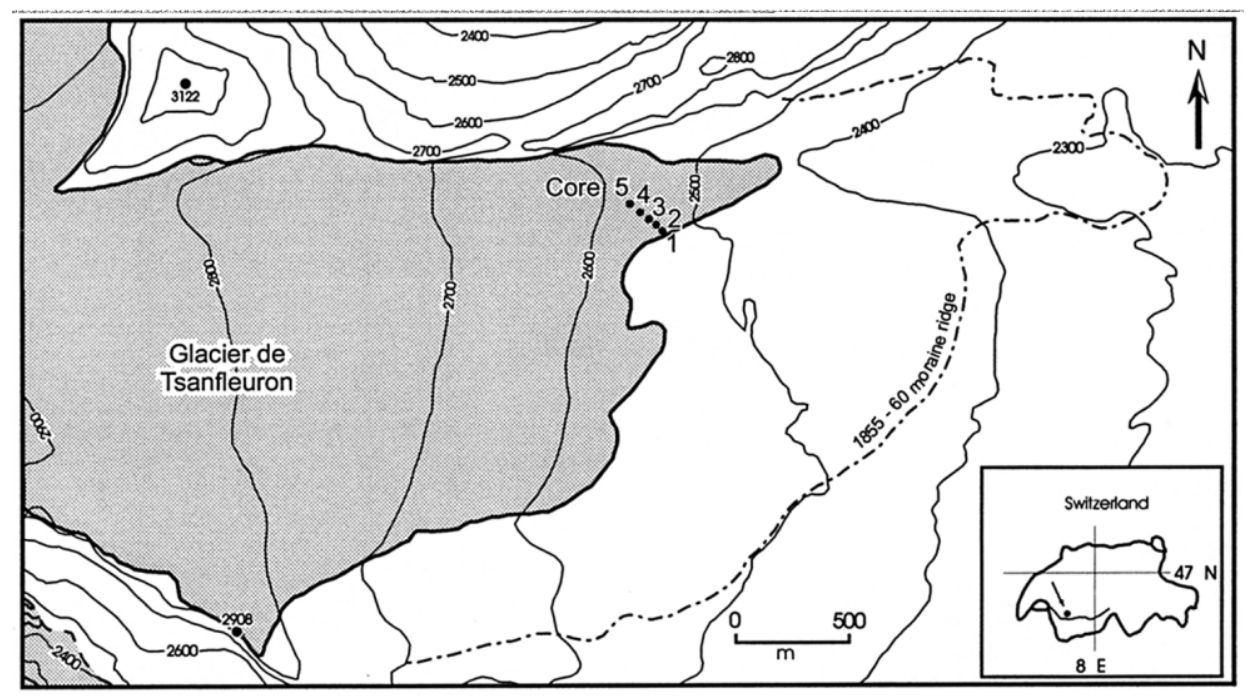

Fig. 1. Map of Glacier de Tsanfleuron, Switzerland, showing ice-core locations. 


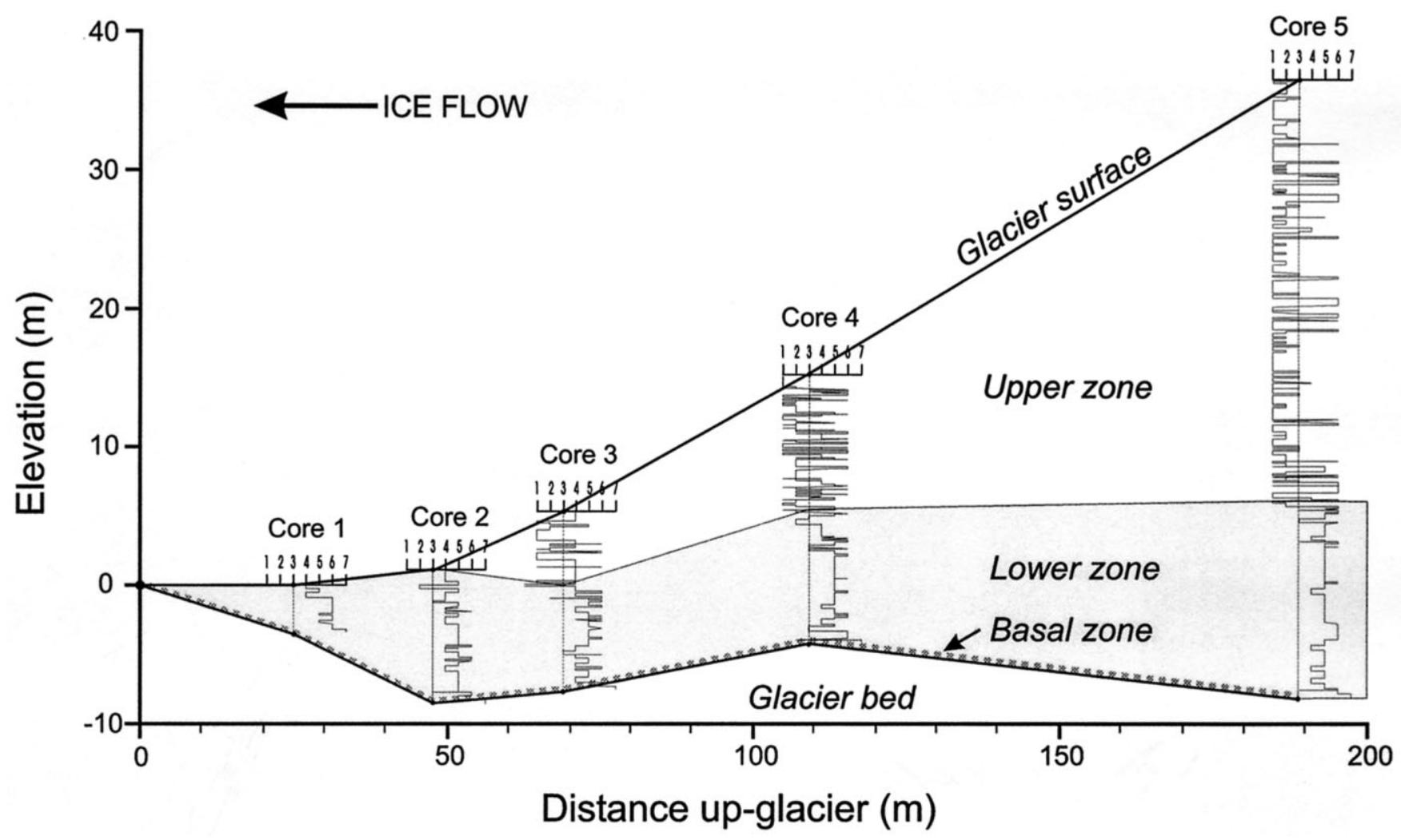

Fig. 2. Ice-type stratigraphies for each of the five ice cores. Stratigraphic logs represent the presence of ice types 1-7 as defined in Table 2.

composed of ice of types 4-6. Application of this definition to the core stratigraphies presented in Figure 2 reveals that LZ and BZ thicknesses are 8-14 and $0.3-0.95 \mathrm{~m}$, respectively (Table 3). The BZ, type 7 ice corresponds visually with dispersed-facies basal ice identified by Hubbard and Sharp (1995). Close examination of Figure 2 also reveals that individual lengths of type 1 englacial ice rarely exceed $1 \mathrm{~m}$ without being interrupted by some decimetres of types 3-6 ice, even in the upper sections of the longer cores, 4 and 5 .

\section{Ice characteristics}

Major-ion concentration, stable-isotope composition and gas content and composition were determined using lengths of core that were short enough to provide high-resolution records of variability within and between individual ice types and zones. Because economic constraints limited the total number of samples that could be analyzed, sampling focused on specific core sections (particularly from core 5) and was not, therefore, continuous over the entire length of any of the cores.

\section{Major-ion concentration}

Major-ion concentrations were determined for 253 samples. Mean concentrations for all samples range from $0.78 \mu \mathrm{eq} \mathrm{L}^{-1}$ $\mathrm{Mg}^{2+}$ to $33.75 \mu \mathrm{eq} \mathrm{L}^{-1} \mathrm{HCO}_{3}{ }^{-}$(Table 4). These concentration ranges are consistent with those of Fairchild and others (1994). Ionic concentration data were also subsampled by zone, and the significance of differences between these sample sets evaluated by $t$-test statistics (Table 5 ). With the exception of debris-rich, type 7 ice, there is no evidence for significant ionic differentiation between individual ice types. As a sample group, however, debris-free LZ ice is significantly enriched in $\mathrm{Na}^{+}, \mathrm{Mg}^{2+}, \mathrm{Ca}^{2+}, \mathrm{NO}_{3}{ }^{-}$and $\mathrm{HCO}_{3}{ }^{-}$relative to the UZ ice (given by bold numbers in Table 5). Downcore plots of individual species for core 5 (Fig. 3) indicate that this enrichment is principally confined to ice (mainly types 4-6) located within a few decimetres of the glacier bed, just above the type 7, BZ ice (Fig. 2). Significantly, concentrations of crustally derived species, in particular $\mathrm{Ca}^{2+}$ (Fig. 4), $\mathrm{Mg}^{2+}$ and $\mathrm{HCO}_{3}^{-}$, increase approximately logarithmically between depths of $\sim 43.80 \mathrm{~m}$ (where their concentration ap-

Table 4. Summary of ionic chemistry data, classified by zone. Standard deviations are given in parentheses

\begin{tabular}{|c|c|c|c|c|c|c|c|c|c|}
\hline Sample & $\mathcal{N}$ & $\mathrm{Na}^{+}$ & $K^{+}$ & $\mathrm{Mg}^{2+}$ & $\begin{array}{c}\mathrm{Ca}^{2+} \\
\mu \text { eq } \mathrm{L}^{-1}\end{array}$ & $C t$ & $\mathrm{NO}_{3}^{-}$ & $\mathrm{SO}_{4}^{2-}$ & $\mathrm{HCO}_{3}{ }_{3}^{-}$ \\
\hline All & 253 & $\begin{array}{c}7.55 \\
(3.26)\end{array}$ & $\begin{array}{c}0.78 \\
(0.57)\end{array}$ & $\begin{array}{c}2.17 \\
(9.40)\end{array}$ & $\begin{array}{c}29.40 \\
(103)\end{array}$ & $\begin{array}{r}2.43 \\
(1.72)\end{array}$ & $\begin{array}{r}2.28 \\
(1.96)\end{array}$ & $\begin{array}{c}1.28 \\
(1.07)\end{array}$ & $\begin{array}{c}33.75 \\
(110.86)\end{array}$ \\
\hline $\mathrm{UZ}$ & 122 & $\begin{array}{c}6.13 \\
(2.92)\end{array}$ & $\begin{array}{c}0.70 \\
(0.49)\end{array}$ & $\begin{array}{c}0.63 \\
(0.29)\end{array}$ & $\begin{array}{c}7.74 \\
(3.60)\end{array}$ & $\begin{array}{r}2.28 \\
(1.61)\end{array}$ & $\begin{array}{c}1.71 \\
(1.13)\end{array}$ & $\begin{array}{c}1.15 \\
(0.45)\end{array}$ & $\begin{array}{l}10.05 \\
(5.33)\end{array}$ \\
\hline LZ & 123 & $\begin{array}{c}8.97 \\
(3.03)\end{array}$ & $\begin{array}{c}0.81 \\
(0.62)\end{array}$ & $\begin{array}{c}0.75 \\
(0.28)\end{array}$ & $\begin{array}{l}14.91 \\
(12.67)\end{array}$ & $\begin{array}{r}2.64 \\
(1.84)\end{array}$ & $\begin{array}{l}2.89 \\
(2.41)\end{array}$ & $\begin{array}{c}1.17 \\
(0.53)\end{array}$ & $\begin{array}{l}18.75 \\
(13.30)\end{array}$ \\
\hline $\mathrm{BZ}$ & 8 & $\begin{array}{r}7.40 \\
(2.16)\end{array}$ & $\begin{array}{c}1.60 \\
(0.42)\end{array}$ & $\begin{array}{l}47.45 \\
(27.48)\end{array}$ & $\begin{array}{l}581.34 \\
(131.76)\end{array}$ & $\begin{array}{r}1.46 \\
(0.45)\end{array}$ & $\begin{array}{c}1.59 \\
(1.07)\end{array}$ & $\begin{array}{l}4.94 \\
(4.11)\end{array}$ & $\begin{array}{c}629.79 \\
(144.02)\end{array}$ \\
\hline
\end{tabular}




\begin{tabular}{|c|c|c|c|c|c|c|c|c|c|}
\hline $\begin{array}{l}\text { Relationship between sample set } \\
\text { values tested }\end{array}$ & $t_{\text {crit. }}$ & $\mathrm{Na}^{+}$ & $K^{+}$ & $\mathrm{Mg}^{2+}$ & $\mathrm{Ca}^{2+}$ & $C l$ & $\mathrm{NO}_{3}^{-}$ & $\mathrm{SO}_{4}{ }^{2-}$ & $\mathrm{HCO}_{3}$ \\
\hline $\mathrm{LZ}>\mathrm{UZ}$ & 2.35 & 7.45 & 1.59 & 3.36 & 6.01 & 1.62 & 4.88 & 0.27 & 6.70 \\
\hline BZ $>$ All samples & 2.90 & -0.18 & 5.13 & 4.50 & 11.44 & -4.98 & -1.68 & 2.44 & 11.31 \\
\hline $\mathrm{BZ}>\mathrm{LZ}$ & 2.82 & -1.83 & 4.63 & 4.50 & 11.37 & -4.99 & -2.82 & 2.43 & 11.22 \\
\hline
\end{tabular}

Notes: Positive values indicate that the concentration contrast for that ion is in accordance with the mathematical operator $(>)$ in column 1 , and conversely. Significant differences are given in bold.

proximates the mean of all LZ samples; Table 4; Fig. 4) and $44.40 \mathrm{~m}$, the top of the (debris-rich) type 7 ice layer. This BZ, type 7 ice is, in turn, significantly enriched in $\mathrm{K}^{+}$, $\mathrm{Mg}^{2+}, \mathrm{Ca}^{2+}$ and $\mathrm{HCO}_{3}{ }^{-}$relative both to all other core samples and to LZ samples (Table 5). In accordance with Fairchild and others (1994), the ionic composition of this debris-rich ice is dominated by crustally derived species, in particular $\mathrm{HCO}_{3}{ }^{-}, \mathrm{Ca}^{2+}$ and $\mathrm{Mg}^{2+}$. In contrast, concentrations of atmospherically derived ions (in particular $\mathrm{Na}^{+}, \mathrm{Cl}^{-}$ and $\mathrm{NO}_{3}{ }^{-}$) are lower in $\mathrm{BZ}$ ice samples (significantly lower in the case of $\mathrm{Cl}^{-}$and $\mathrm{NO}_{3}{ }^{-}$) than in the overlying, debris-free ice column.

\section{Stable-isotope composition}

$\delta^{18} \mathrm{O}$ and $\delta \mathrm{D}$ were determined for 153 samples from core 5 . Mean compositions for the entire core were $-12.7 \%$ in $\delta^{18} \mathrm{O}$ and $-91 \%$ in $\delta \mathrm{D}$ (Table 6 ). However, down-core variability in stable-isotope composition is apparent (Fig. 5). In particular, these data reveal two core sections that are characterised by anomalous isotopic compositions: a section of heavy-isotope depletion between $\sim 32$ and $\sim 33 \mathrm{~m}$ depth, and heavyisotope enrichment in the debris-rich, basal ice layer. The $\delta^{18} \mathrm{O}$ composition of ice in the former narrow band is depleted by $\sim 1 \%$ relative to the mean composition of samples from the rest of the core, with the lightest sample from $31.8-33.3 \mathrm{~m}$ being - $14.6 \%$ in $\delta^{18} \mathrm{O}$. The mean $\delta^{18} \mathrm{O}$ composition of the type 7 , BZ ice is $-11.1 \%$, contrasting strongly with a value of $12.8 \%$ for the rest of the core. Corresponding patterns in both of these anomalous zones are recorded in the $\delta \mathrm{D}$ signal. There is no evidence for significant isotopic variability between the ice of the UZ and the LZ (Table 6), or for heavy-isotope enrichment in types 4-6 (LZ) ice located close to the glacier bed (Fig. 5).

Least-squares linear regression of bivariate co-isotopic plots of these sample groups reveals some variability in slope (Fig. 6). Samples other than those located at 31.8-33.3 $\mathrm{m}$ and those comprising the BZ define a slope of $6.9( \pm 0.30$ at $P=$ 0.05). This is in close agreement with the co-isotopic composition of "unaltered" surface-ice samples recovered from the glacier by Hubbard and Sharp (1995). In contrast, isotopically light samples recovered from 31.8-33.3 m define a slope of 6.0 ( \pm 0.49$)$, and isotopically heavy, BZ ice samples define a co-isotopic slope of $6.3( \pm 1.30)$.Gas content and composition

Total gas content was determined for 44 ice samples, of which 28 were analyzed for $\mathrm{CO}_{2}, \mathrm{O}_{2}$ and $\mathrm{N}_{2}$ concentrations. Since ice types 6 and 7 are visually bubble-free, only four samples of the former and none of the latter were analyzed. Total gas content for all 44 samples ranges from $<0.005$ to $0.035 \mathrm{~mL} \mathrm{~g}_{\text {ice }}{ }^{-1}$. This range is consistent with, but extends lower than, that reported in surface ice close to the terminus of Griesgletscher, Switzerland, by Berner and others (1977). As expected on the basis of visual classification, total gas content varies inversely with ice type, ranging from $0.028 \mathrm{~mL} \mathrm{~g}_{\text {ice }}{ }^{-1}$ for type 1 ice to $0.010 \mathrm{~mL} \mathrm{~g}_{\text {ice }}{ }^{-1}$ for type 5 ice and $<0.005 \mathrm{~mL} \mathrm{~g}_{\text {ice }}{ }^{-1}$ for all four type 6 ice samples (Table 7). Plotting total gas content, $\mathrm{CO}_{2}$ concentration and $\mathrm{O}_{2} / \mathrm{N}_{2}$
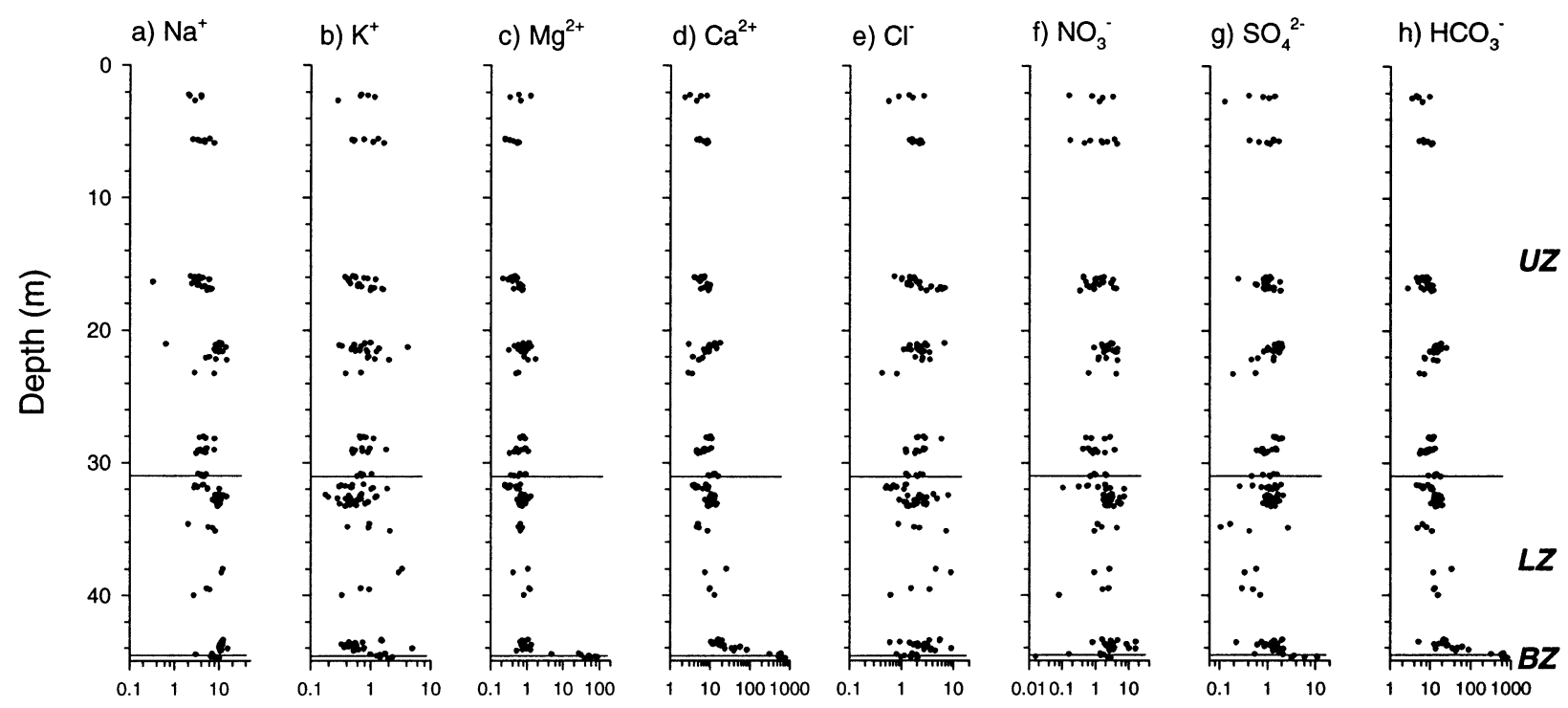

\section{Concentration ( $\mu \mathrm{eq} \mathrm{L}^{-1}$ )}

Fig. 3. Major-ion concentrations measured in core 5. The horizontal lines at $\sim 30.8$ and $\sim 44.4$ m mark, respectively, the boundaries between the UZ and the LZ and the LZ and the BZ. 


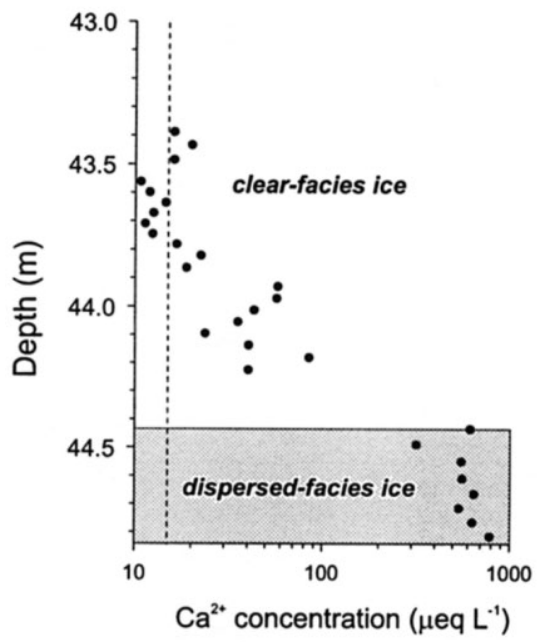

Fig. 4. $\mathrm{Ca}^{2+}$ concentrations measured at the base of core 5. Note enhanced concentrations in the clean ice located at 43.8$44.4 \mathrm{~m}$, immediately above the type 7, dispersed-facies BZice (shaded). The dashed line gives the mean $\mathrm{Ca}^{2+}$ concentration for all $\mathrm{LZ}$ samples. Similar patterns are evident in plots of $\mathrm{Mg}^{2+}$ and $\mathrm{HCO}_{3}{ }^{-}$.

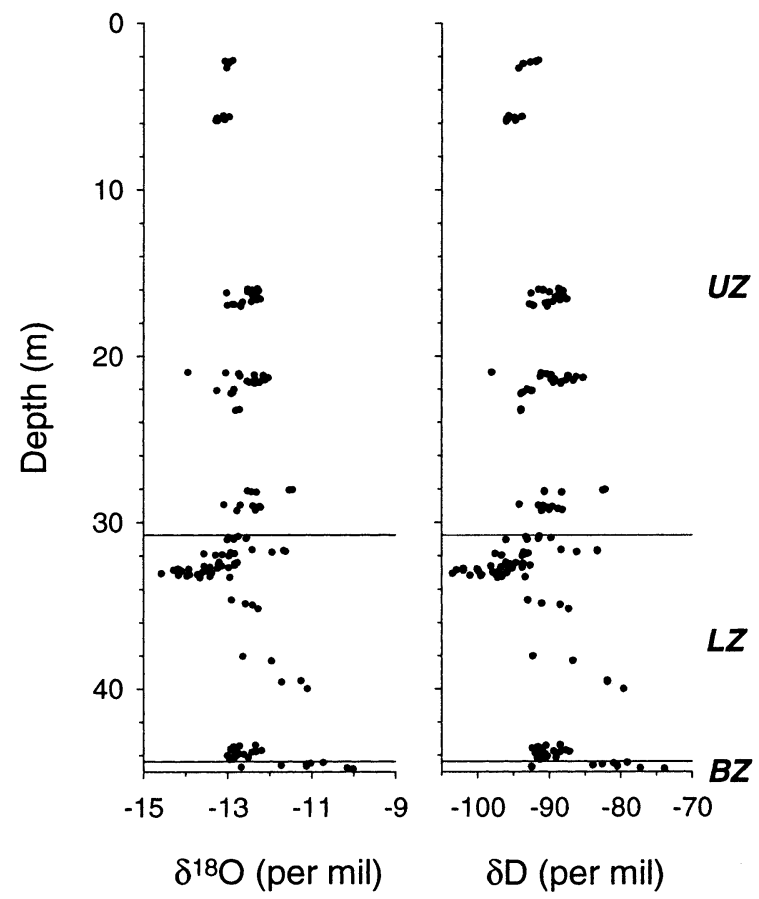

Fig. 5. Stable-isotope ratios measured in core 5. The horizontal lines at $\sim 30.8$ and $\sim 44.4 \mathrm{~m}$ mark, respectively, the boundaries between the $U Z$ and the $L Z$ and the $L Z$ and the BZ.

Table 6. Stable-isotope summary data for core 5

\begin{tabular}{|c|c|c|c|c|c|}
\hline \multirow[t]{3}{*}{ Sample } & \multirow[t]{3}{*}{$\mathcal{N}$} & \multicolumn{2}{|c|}{$\delta^{18} \mathrm{O}$} & \multicolumn{2}{|c|}{$\delta \mathrm{D}$} \\
\hline & & Mean & Std dev. & Mean & Std dev. \\
\hline & & $\%$ & & $\%$ & \\
\hline All samples & 153 & -12.69 & 0.71 & -91.25 & 4.92 \\
\hline All UZ & 72 & -12.61 & 0.42 & -90.70 & 3.04 \\
\hline All LZ & 73 & -12.94 & 0.69 & -92.90 & 5.02 \\
\hline All BZ & 8 & -11.08 & 0.85 & -81.4 & 5.48 \\
\hline Ice types 1-6 & 145 & -12.78 & 0.59 & -91.8 & 4.29 \\
\hline $31.8-33.3 \mathrm{~m}$ & 33 & -13.47 & 0.50 & -97.03 & 3.05 \\
\hline $0-31.8$ and $33.3-45 \mathrm{~m}$ & 120 & -12.47 & 0.61 & -89.66 & 4.08 \\
\hline
\end{tabular}

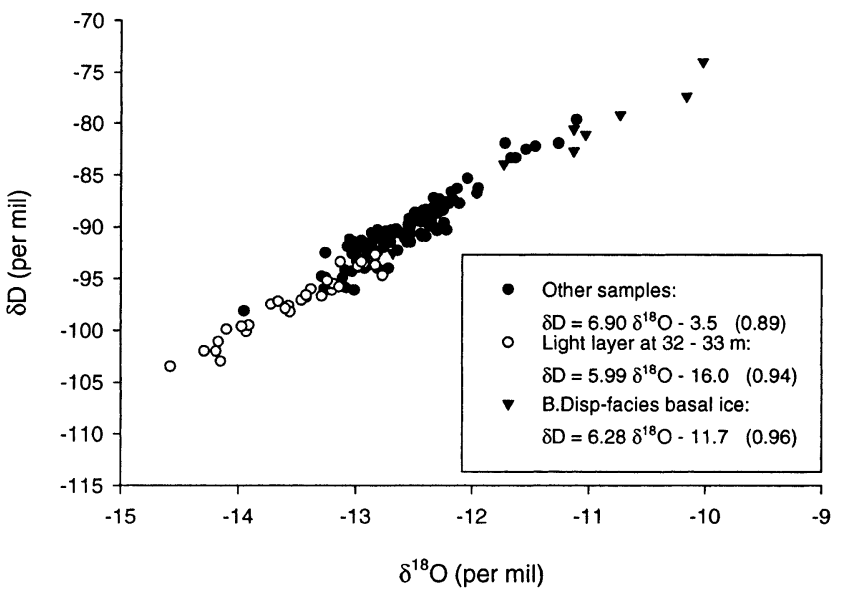

Fig. 6. Bivariate co-isotopic plot of ice samples recovered from core 5. Least-squares linear regression statistics are presented for selected sample sub-groups ( $r^{2}$ values are given in parentheses).

ratio against ice type (under the assumption that ice types 6 and 7 contain no gas) reveals a strong negative relation in the case of total gas content, but weaker positive and negative relationships, respectively, for $\mathrm{CO}_{2}$ concentration and $\mathrm{O}_{2} / \mathrm{N}_{2}$ ratio (Fig. 7).

Analysis of gas characteristics along core 5 (32 samples, of which 17 were analyzed for $\mathrm{CO}_{2}, \mathrm{O}_{2}$ and $\mathrm{N}_{2}$ concentrations) reveals systematic trends in both total gas content and gas composition (Fig. 8). As expected on the basis of core stratigraphy, total included gas content is markedly lower in the LZ and BZ than in the UZ (Fig. 8a). Typical UZ gas concentrations exceed $0.02 \mathrm{~mL} \mathrm{~g}_{\text {ice }}{ }^{-1}$ (mean $=0.025 \mathrm{~mL} \mathrm{~g}_{\text {ice }}{ }^{-1}$ ), while $\mathrm{LZ}$ concentrations are generally well below this value (mean $=0.010 \mathrm{~mL}_{\text {ice }}{ }^{-1}$ ), commonly falling below the analytical detection limit. Initial examination of Figure 8a indicates that total gas content falls steadily (at a rate of about $0.005 \mathrm{~mL} \mathrm{~g}_{\text {ice }}{ }^{-1}$ per $10 \mathrm{~m}$ depth) throughout the entire core length, rather than in a step-like manner at the UZ/LZ transition. This effect, however, may be an artefact of our sampling strategy, from which the analysis of bubble-free ice of types 6 and 7 was largely excluded (above). Since these ice types account for a markedly higher proportion of the LZ than of the UZ (Fig. 2), their under-representation results in a statistical over-calculation of the total gas content of the LZ. With this sampling bias in mind, we have constructed a proxy record of total gas content for core 5 by matching the core's ice-type stratigraphy (Fig. 2) to the total gas content predicted (Table 7) on the basis of the bi-

Table 7. Summary gas data, classified by ice type

\begin{tabular}{|c|c|c|c|c|c|c|}
\hline \multirow[t]{3}{*}{ Ice type } & \multicolumn{2}{|c|}{ Total gas content } & \multirow[t]{3}{*}{$\mathcal{N}$} & \multirow{3}{*}{$\begin{array}{c}\mathrm{CO}_{2} \\
\operatorname{Mean}(\sigma) \\
\operatorname{ppm}\end{array}$} & \multirow{3}{*}{$\begin{array}{c}\mathrm{O}_{2} / \mathcal{N}_{2} \\
\operatorname{Mean}(\sigma) \\
\%\end{array}$} & \multirow[t]{3}{*}{$\mathcal{N}$} \\
\hline & $\operatorname{Mean}(\sigma)$ & Predicted & & & & \\
\hline & $\mathrm{mL} \mathrm{g}_{\text {ice }}{ }^{-1}$ & $\mathrm{~mL} g_{\text {ice }}{ }^{-1}$ & & & & \\
\hline 1 & $0.028(0.009)$ & 0.0296 & 12 & $173(127)$ & $0.172(0.036)$ & 8 \\
\hline 2 & $0.021(0.003)$ & 0.0245 & 4 & $82(34)$ & $0.105(0.017)$ & 3 \\
\hline 3 & $0.024(0.009)$ & 0.0193 & 4 & $208(134)$ & $0.113(0.045)$ & 3 \\
\hline 4 & $0.018(0.008)$ & 0.0142 & 5 & $174(122)$ & $0.155(0.058)$ & 5 \\
\hline 5 & $0.010(0.006)$ & 0.0091 & 15 & $385(245)$ & $0.100(0.022)$ & 9 \\
\hline 6 & $<0.005(-)$ & 0.0000 & 4 & - & - & 0 \\
\hline 7 & - & - & 0 & - & - & 0 \\
\hline
\end{tabular}

Notes: Predicted total gas content (column 3) is calculated on the basis of the bivariate plot of total gas content against ice type (Fig. 7), except ice types 6 and 7, which are assumed to be zero. 


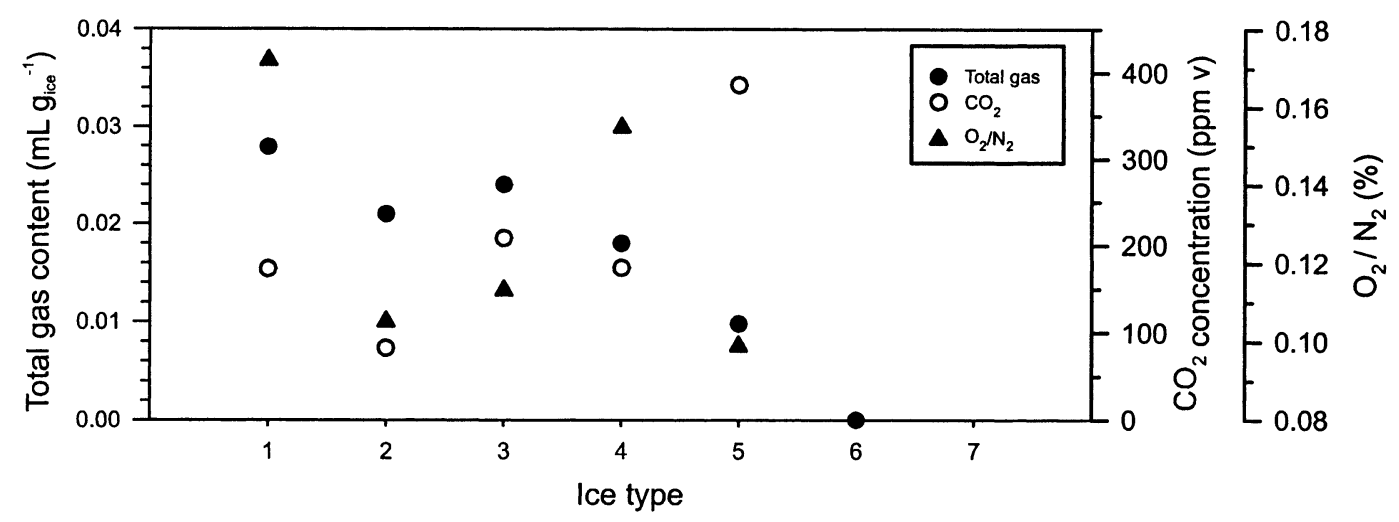

Fig. 7. Bivariate plot of mean total gas content, $\mathrm{CO}_{2}$ concentration and $\mathrm{O}_{2} / \mathcal{N}_{2}$ against ice type.

variate plot presented in Figure 7. While the accuracy of this technique is limited by variability in the relationship between ice type and total gas content, it does give a valid, alternative record of the pattern of change in total gas content along the core. In contrast to the raw data, this proxy record reveals a much stronger change in total gas content across the UZ/LZ boundary (Fig. 8a).

In contrast to total gas content, a similar reconstruction of down-core patterns of $\mathrm{CO}_{2}$ concentration and $\mathrm{O}_{2} / \mathrm{N}_{2}$ ratio from ice-type data cannot be justified, since no type 6 or 7 gas composition data were available to plot against ice type (Fig. 7). The raw data, however, reveal that $\mathrm{CO}_{2}$ concentration rises from $\sim 100 \mathrm{ppmv}$ at the top of the core to almost 600 ppmv at the base (Fig. 8b), while $\mathrm{O}_{2} / \mathrm{N}_{2}$ falls from a maximum value of 0.245 near the top of the core to a minimum value of 0.085 close to the glacier bed (Fig. 8c). Although $\mathrm{O}_{2}$ $\mathrm{N}_{2}$ appears to fall steadily along the entire core length, we have insufficient data to determine whether this decrease is characterised by a step at the UZ/LZ boundary. Sparse sampling also makes it difficult to identify any definite trend in $\mathrm{CO}_{2}$ concentration through the $\mathrm{UZ}$ (mean $=126 \mathrm{ppmv}$ ), although there is evidence of a rapid downward increase through the LZ. The only samples with $\mathrm{CO}_{2}$ concentrations that are greater than atmospheric $(\sim 360 \mathrm{ppmv})$ are located towards the base of the $\mathrm{LZ}$ (the highest measured $\mathrm{CO}_{2}$ concentration, 837 ppmv, was recorded within $1 \mathrm{~m}$ of the base of core 4).

\section{INTERPRETATION AND DISCUSSION}

The LZ is principally composed of ice types $4-6$. It is therefore largely devoid of both debris and high densities of small bubbles. These properties are similar to those that define clear-facies ice identified at the beds of numerous temperate-based glaciers (e.g. Theakstone, 1979; Hubbard and Sharp, 1995; Jansson and others, 1996), and we therefore equate the two. Ice cores recovered for the present study, however, reveal that clear-facies ice is $>10 \mathrm{~m}$ thick. This is similar to the thickness of largely bubble-free blue ice identified at the base of a core drilled to the bed in the accumulation area of Vallée Blanche, France (Vallon and others, 1976) and observed in a subglacial gallery at Engabreen, Norway (personal communication from J. Kohler, 1999). However, it is markedly greater than the thickness generally inferred from previous observations made in natural basal cavities (e.g. Theakstone, 1979; Hubbard and Sharp, 1995). While assessing the thickness of clear-facies ice from basal cavities is difficult, this discrepancy may also reflect vari- a)

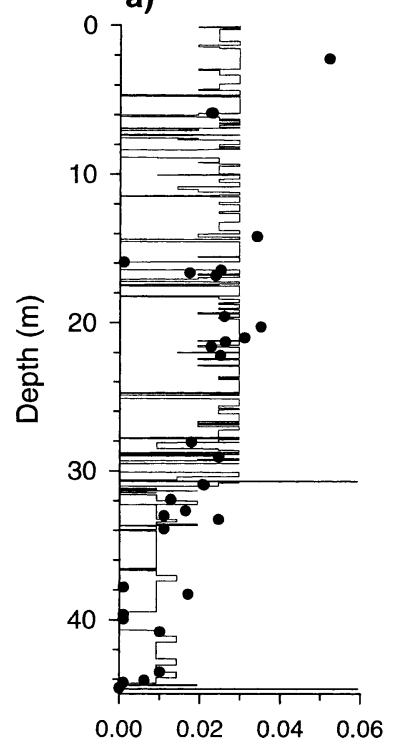

Total gas content $\left(\mathrm{mL} \mathrm{g}_{\mathrm{ice}}{ }^{-1}\right)$ b)

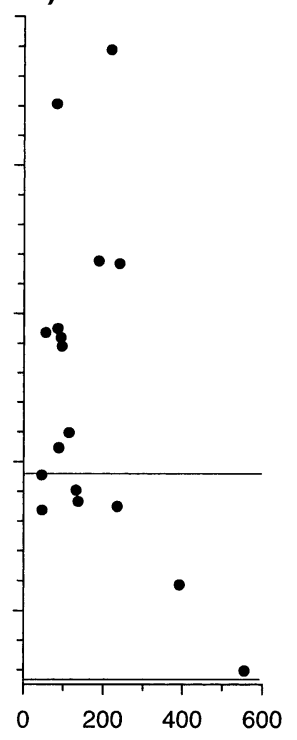

$\mathrm{CO}_{2}$ concentration (ppmv) c)

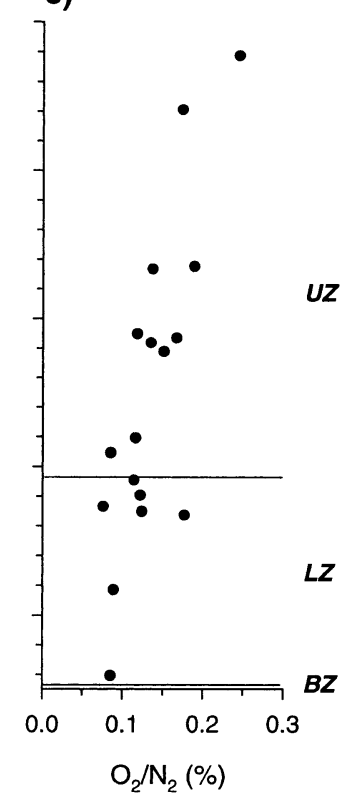

Fig. 8. Included gas characteristics measured in core 5: (a) total gas content, including that both measured (solid dots) and reconstructed from ice-type stratigraphy (solid line; see text for explanation); (b) $\mathrm{CO}_{2}$ concentration; (c) $\mathrm{O}_{2} / \mathcal{N}_{2}$. The horizontal lines at $\sim 30.8$ and $\sim 44.4 \mathrm{~m}$ mark, respectively, the boundaries between the $U Z$ and the $L Z$ and the LZ and the BZ. 
ations in the largely qualitative and visually based facies definitions adopted by researchers to date. In the present study, clear-facies ice is defined semi-quantitatively as being devoid of any ice that contains a medium or high density of small bubbles (Tables 1 and 2). This definition effectively distinguishes clear-facies ice from the overlying, bubble-foliated englacial ice that forms by firnification near the glacier surface.

However, bubble-free ice is at least intermittently present throughout our ice cores: as thin $(<60 \mathrm{~mm})$ layers forming folia and thick $(>60 \mathrm{~mm})$ layers disrupting folia in the $\mathrm{UZ}$, as massive clear-facies ice in the $\mathrm{LZ}$ and as dispersedfacies basal ice in the BZ. A number of possible processes may be invoked to explain the formation of such bubblepoor ice. These may be broadly divided into near-surface, englacial and basal processes.

\section{Near-surface processes of bubble-poor ice formation}

These include surface crevasse or crack fills, and the freezing of percolating meltwater within the surface snowpack or firn layer. The latter will tend to be thin, probably on the order of $10^{-2} \mathrm{~m}$, forming layers or lenses that are broadly conformable with primary stratification. Crevasse fills may be slightly thicker, perhaps up to $10^{\circ} \mathrm{m}$, may cut across dominant stratification and foliation at a high angle and are likely to be separated from each other by at least $10^{\circ} \mathrm{m}$ of normal englacial ice (e.g. Pohjola, 1994).

\section{Englacial processes of bubble-poor ice formation}

These include gas removal by meltwater generated by deformation-related grain-boundary melting and refreezing, and the local storage and/or refreezing of gas-poor meltwaters percolating through the ice. The former process would be expected to result in the gradual formation of a massive bubble-free ice layer that may be isotopically heavy relative to its initial composition (Hubbard and Sharp, 1995). In contrast, local meltwater storage and/or refreezing would affect a thinner layer of ice that may be isotopically light relative to its initial composition.

\section{Basal processes of bubble-poor ice formation}

These involve either the formation of a basal ice layer by basal adfreezing or regelation, or the pressurised transfer of basal meltwater into and through the overlying ice. Ice layers formed by the former process are likely to contain more debris than overlying englacial ice, and are unlikely to be thicker than $10^{\circ} \mathrm{m}$ at predominantly temperate-based glaciers (Hubbard and Sharp, 1989). Basal ice layers affected by the latter process may be isotopically heavy, and are predicted to be no thicker than $10^{-1} \mathrm{~m}$ (e.g. Lliboutry, 1993).

The geometry, location and stratigraphy of the $<60 \mathrm{~mm}$ thick, bubble-poor ice layers contained within type 1 ice at Glacier de Tsanfleuron strongly indicate a near-surface origin as ice layers or lenses formed from the refreezing of percolating meltwaters. Such processes universally accompany seasonally variable firnification, resulting in the formation of bubble-foliated englacial ice (e.g. Hambrey, 1975; Hooke and Hudleston, 1978). In contrast, the thicker (>60 mm) layers of bubble-poor ice present throughout the UZ show some evidence of increasing in both thickness and frequency with depth (Fig. 2). These characteristics suggest an englacial mode of formation. However, the scale and frequently repeated occurrence of these layers reduces the likelihood of formation as local zones of meltwater storage or as healed crevasses. We therefore believe these layers are formed in response to locally enhanced ice deformation and associated internal meltwater generation. They may be similar to the layers observed by Raymond and Harrison (1975), who identified metre-long, bubble-free sections of ice core at depths of 10, 20 and $23 \mathrm{~m}$ at Blue Glacier, U.S.A.

LZ clear-facies ice is massive, predominantly debris-free and $\sim 10 \mathrm{~m}$ thick, precluding formation as a result of nearsurface or basal processes. The facies therefore appears to form englacially: by deformation-related meltwater generation and removal, and/or by local storage or refreezing of percolating meltwaters. The former process is favoured, since, with the exception of the ice layer located at $\sim 33 \mathrm{~m}$ depth in core 5 (discussed below), there is no evidence that clear-facies ice is isotopically lighter than overlying englacial ice. Further, the general down-core decrease in total gas content and the ratio of (more soluble) $\mathrm{O}_{2}$ to (less soluble) $\mathrm{N}_{2}$ in core 5 (Fig. 8c) is broadly consistent with the removal of gas in solution along triple-grain veins during such a process. Our evidence is therefore consistent with deformationrelated, bubble-free ice formation as distinct, $10^{-1} \mathrm{~m}$ thick layers within the UZ (perhaps increasing in scale and frequency with depth) and as a massive $10^{1} \mathrm{~m}$ thick layer within the LZ. This interpretation implies that deformation is similarly distributed, being focused along relatively discrete planes in the UZ and operating more or less pervasively through the LZ. In this case, the stratigraphic location of the transition between the UZ and the LZ may be related to a rapid increase in ice deformation as shear strain rate increases non-linearly with depth, perhaps supplemented by a local threshold in the response of ice metamorphism to deformation rate.

Bubble-poor, dispersed-facies basal ice is isotopically heavy and located within $10^{\circ} \mathrm{m}$ of the glacier bed. The facies is also debris-rich, merging into the overlying clear-facies ice via an increase in the spacing between, and a decrease in the thickness of, individual debris-rich bands. These properties are consistent with formation by refreezing at the basal interface, perhaps supplemented by permeating basal water flow, and have been analyzed in detail elsewhere (Tison and Lorrain, 1987; Hubbard and Sharp, 1995).

A $\sim 1 \mathrm{~m}$ thick layer of bubble-poor ice that is isotopically light and characterised by an anomalously low co-isotopic slope is located just below the top of the clear-facies ice layer in core $5, \sim 12 \mathrm{~m}$ above the glacier bed. Statistical testing indicates that the isotopic composition of this layer is significantly ( $P=0.05)$ different from that of the remainder of the ice core, suggesting the influence of a specific physical process, either during the formation of this layer or during its subsequent flow through the glacier. Since this layer is isotopically distinct from adjacent clear-facies ice, an alternative or supplementary mode of formation is sought. Two explanations for the bubble-poor and isotopically light character of the layer seem feasible: formation (1) as a crevasse fill near the ice surface, and (2) by the trapping of percolating water in an englacial location. In either case, the isotopic character of the layer is consistent with a water source supplied by meltingrefreezing processes within overlying ice or snow. Herrmann and others (1981) added water to the upper surface of a recrystallising, temperate snow column and sampled the outflow as it emerged from the column's base. The first $50 \%$ of the outflow was isotopically lighter than the initial water and snow, and was aligned on a (relatively low) co-isotopic slope of 6.3. The generation of such water is possible both at the surface of 
Glacier de Tsanfleuron and within the body of the glacier, in the former case from the base of the seasonal snowpack and in the latter from melting and incomplete refreezing within overlying ice. For percolating meltwater to be preferentially accumulated within this layer, the layer must be more permeable than the surrounding ice, and/or overlie ice that is relatively impermeable, creating a perched water table. It may therefore be significant that the isotopically light layer is located near the top of the LZ in core 5, since ice character (and therefore, to some extent, its permeability) changes at this location. The possibility that the isotopically light layer may be (or have been) more permeable than the overlying englacial ice is not surprising given the sharp local reduction in gas-bubble concentration across the UZ/LZ boundary. Such bubbles serve to impede inter-granular water flow both by blocking veins directly (e.g. Lliboutry, 1971; Raymond and Harrison, 1975) and, where pressurised, by freezing vein waters (Raymond, 1976). These processes, however, cannot easily be invoked to explain reduced permeability immediately beneath $\sim 33 \mathrm{~m}$, although such an effect could be related to intense ice deformation and crystallographic changes in this zone (Lliboutry, 1971). Such influences, however, are currently unconstrained, pending future detailed investigations of ice structure and crystallography over the UZ/LZ transition.

The percentage mass of influent, isotopically light vein water required to produce the measured isotopic shift at $\sim 33 \mathrm{~m}$ in core 5 may be approximated from simple massbalance considerations. Here:

$$
\delta_{\mathrm{f}}=\left[\delta_{\mathrm{i}}(1-\mathrm{V})\right]+\left(\delta_{\mathrm{p}} \mathrm{V}\right),
$$

where $\delta_{\mathrm{f}}$ and $\delta_{\mathrm{i}}$ are, respectively, the final and initial isotopic compositions of the ice layer affected and $V$ is the mass proportion of the final ice layer composed of influent, percolating meltwater of isotopic composition $\delta_{\mathrm{p}}$. For $\delta^{18} \mathrm{O}$, our measurements indicate that $\delta_{\mathrm{f}}=-13.47 \%$ and that $\delta_{\mathrm{i}}$ (for UZ ice $)=-12.61 \%$ (Table 6 ). We assume that the composition of $\delta_{\mathrm{p}}$ corresponds to the final $5 \%$ unfrozen fraction of a liquid with an initial isotopic composition similar to that of the initial ice, $\delta_{\text {i }}$ (i.e. $-12.61 \%$ ). Following Jouzel and Souchez (1982), the isotopic composition of ice $\left(\delta_{\mathrm{S}}\right)$ formed by closed system freezing is:

$$
\delta_{\mathrm{s}}=10\left(1000+\delta_{0}\right)\left[(1.1-K)^{f}-(1-K)^{f}\right]-1000,
$$

where $\delta_{0}$ is the initial composition of the parent water, $K$ is the equilibrium fractionation coefficient between water and ice, and $f$ is the proportion of the parent water source that is frozen. Substituting $\delta_{0}=-12.61 \%, K=1.00291$ (Lehmann and Siegenthaler, 1991) and $f=0.95$ into Equation (2) gives a bulk newly formed ice composition of $-12.21 \%$ in $\delta^{18} \mathrm{O}$. The corresponding composition of the unfrozen liquid remaining at $f=0.95$ (and thus $\delta_{\mathrm{p}}$ in Equation (1)) is $-20.21 \%$. Substituting these isotopic values into Equation (1) and solving for $V$ indicates that $\sim 11 \%$ of the $1 \mathrm{~m}$ thick ice layer located at $\sim 33 \mathrm{~m}$ depth in core 5 needs to be composed of isotopically light influent water. Since temperate ice typically contains $<2 \%$ liquid water (e.g. Raymond and Harrison, 1975; Lliboutry, 1976), much of the postulated storage within this layer must be in the form of refrozen ice.

Most of the clear-facies (LZ) ice layer is characterised by low ionic concentrations, as is the UZ ice (Table 4). These values conflict with those measured in clear-facies ice samples recovered from basal cavities in previous studies. For example, taking $\mathrm{Ca}^{2+}$ as a crustally derived indicator ion, Hubbard (1992) recorded a mean concentration of
$115 \mu \mathrm{eq} \mathrm{L}{ }^{-1}$ in clear-facies basal ice at Glacier de Tsanfleuron. Similarly, Jansson and others (1996) reported a mean $\mathrm{Ca}^{2+}$ concentration of $51 \mu \mathrm{eq} \mathrm{L}^{-1}$ for a visually similar basal ice layer (their "Unit C") characterised by a mean sediment concentration of $\sim 0.4 \mathrm{~g} \mathrm{~L}^{-1}(0.4 \% \mathrm{wt}$ ) at Engabreen, Norway, which flows over schists and gneisses. In contrast, the mean $\mathrm{LZ} \mathrm{Ca}^{2+}$ concentration in the present study (excluding debris-rich, type 7 ice) is $14.9 \mu \mathrm{eq} \mathrm{L}^{-1}$ (Table 4). The discrepancy between the low ionic concentrations measured in clear-facies ice in the present study and the relatively high ionic concentrations measured in similar ice by Hubbard (1992) and possibly Jansson and others (1996) may reflect a variety of factors. These include sample contamination in difficult conditions at the glacier bed, particularly in the earlier Tsanfleuron study where ice was melted in situ for sampling; the presence of reactive debris entrained within samples of what appeared visually to be clean ice; and, perhaps most significantly, the transport of ionically enriched vein waters upward from the debris-rich basal ice where the solute was acquired. Measurements of enhanced concentrations of crustally derived ions in visibly debris-free, clearfacies ice above the debris-rich, dispersed-facies ice layer in the present study (Fig. 4) suggest that the latter process occurs over a scale of some decimetres. We therefore infer that, while ice metamorphism throughout the entire glacier thickness (but particularly within the LZ and BZ) results in the transfer of meltwaters towards the glacier bed, an active meltwater exchange may occur within a few decimetres of the glacier bed. Where such exchange occurs, concentration gradients in water-borne characteristics, such as ionic and dissolved-gas content, will tend to be reduced. It is interesting to note in this context that the concentration of atmospherically derived species (in particular, $\mathrm{Cl}^{-}$and $\mathrm{NO}_{3}{ }^{-}$) may be depleted within the type 7, BZ ice (Table 5). This scale of proposed vein-water exchange $\left(10^{-2}\right.$ to $\left.10^{-1} \mathrm{~m}\right)$ agrees closely with Lliboutry's (1993) theoretical calculations of the thickness of the basal ice layer that experiences internal regelation cycles resulting from basally induced stresses.

\section{Implications}

Our data suggest that gas is expelled from englacial ice over much of the glacier thickness, and that the effectiveness of this metamorphism is markedly increased within $10-15 \mathrm{~m}$ of the glacier bed, where it results in the formation of a massive layer of clear-facies ice. The physical characteristics of this clear-facies ice are consistent with metamorphism through intense and variable ice deformation and associated internal pressure melting and refreezing. This process of ice metamorphism results in the expulsion of gas and meltwater to the basal interface in a manner that is probably both temporally continuous and spatially extensive. Such a supply of gas and water may have a significant impact on the geochemistry of subglacial water flow in a distributed drainage system, since these are not diluted by large and variable surface-generated meltwater fluxes. Indeed, meltwater samples collected from the bases of boreholes drilled in areas of distributed flow at Haut Glacier d'Arolla, Switzerland, are characterised by ratios of $\mathrm{HCO}_{3}{ }^{-}$to $\mathrm{SO}_{4}{ }^{2-}$ of $2.2: 1$ (Tranter and others, 1997). Such values suggest the presence of a local subglacial $\mathrm{CO}_{2}$ supply, since normal coupled sulphide oxidation-carbonation reactions result in a ratio of $\mathrm{HCO}_{3}{ }^{-}$to $\mathrm{SO}_{4}{ }^{2-}$ of $1: 1$. Gas expulsion during basal ice metamorphism may well contribute to this subglacial $\mathrm{CO}_{2}$ 
supply, the magnitude of which may be approximated in a general manner from our ice-core data. Since clear-facies ice is effectively devoid of gas at its contact with dispersedfacies basal ice, the quantity of $\mathrm{CO}_{2}$ delivered per square metre of bed area per year to the basal interface by clearfacies ice formation $(\xi)$ is equal to the annual thickness of englacial ice that is metamorphosed to clear-facies ice at the UZ/LZ boundary $\left(Q_{\mathrm{ec}}\right)$ multiplied by the initial $\mathrm{CO}_{2}$ concentration of that englacial ice $\left(\mathrm{CO}_{2 \mathrm{e}}\right)$ :

$$
\xi=Q_{\mathrm{ec}} \mathrm{CO}_{2 \mathrm{e}} \text {. }
$$

Here, $\mathrm{CO}_{2 \mathrm{e}}$ is given by the product of the initial total gas content (standard temperature and pressure) of the englacial ice $\left(\sim 0.03 \mathrm{~mL} \mathrm{~g}_{\text {ice }}{ }^{-1}\right.$ for core 5 (or, assuming an ice density of $900 \mathrm{~kg} \mathrm{~m}^{-3}, 27 \mathrm{~L} \mathrm{~m}_{\text {ice }}{ }^{-3}$ ); Table 7; Fig. 8a) and the concentration of $\mathrm{CO}_{2}$ in that gas $(\sim 0.015 \%$ for core 5 ; Table 7; Fig. 8b). At any given time, $Q_{\mathrm{ec}}$ may be considered in terms of (i) the rate of increase of clear-facies ice-layer thickness as it progressively forms from the head of the glacier to the terminus $\left(Q_{\mathrm{ec}(\mathrm{f})}\right)$, and (ii) the maintenance of that thickness as the layer is progressively melted from its base $\left(Q_{\mathrm{ec}(\mathrm{m})}\right)$ (illustrated conceptually in Fig. 9). In approximating $Q_{\mathrm{ec}(\mathrm{f})}$, we assume that the thickness of the clear-facies ice layer increases from zero at the head of the glacier to its maximum thickness at the terminus, such that:

$$
Q_{\mathrm{ec}(\mathrm{f})}=\left(T_{\mathrm{c}} / L\right) U_{\mathrm{b}},
$$

where $T_{\mathrm{c}}$ is the maximum thickness of the clear-facies ice layer at the glacier terminus ( $\sim 10 \mathrm{~m}$; Table 3$), L$ is the glacier length ( $\sim 2000 \mathrm{~m}$; Fig. 1$)$ and $U_{\mathrm{b}}$ is the spatially averaged basal sliding velocity of the glacier $\left(\mathrm{m} \mathrm{a}^{-1}\right)$. We take $U_{\mathrm{b}}$ to be $5 \mathrm{ma}^{-1}$ on the basis of the recorded motion of a marker placed within a cavity beneath the glacier (Hubbard and Hubbard, 1998). Our assumption that the formation of clear-facies ice begins at the head of the glacier is supported by the ice-core records of Vallon and others (1976) reported above. $Q_{\mathrm{ec}(\mathrm{m})}$ may be approximated from:

$$
Q_{\mathrm{ec}(\mathrm{m})}=\left(G_{\mathrm{b}}+F_{\mathrm{b}}+W_{\mathrm{b}}\right),
$$

where the righthand terms are annually and areally integrated basal melt rates due to geothermal heating $\left(G_{\mathrm{b}}\right)$, frictional heating $\left(F_{\mathrm{b}}\right)$ and frictional dissipation of heat in subglacial channels $\left(W_{\mathrm{b}}\right)$. Paterson $(1994$, p. 112) gives typical values of $G_{\mathrm{b}}$ and $F_{\mathrm{b}}$ of $6 \mathrm{~mm} \mathrm{a}^{-1}$ each, and we make the assumption that $W_{\mathrm{b}}$ above a linked-cavity-type drainage system (Sharp and others, 1990) brings the total to
$20 \mathrm{~mm} \mathrm{a}^{-1}$. Thus $Q_{\mathrm{ec}}=0.045 \mathrm{~m} \mathrm{a}^{-1}$, and Equation (3) gives a specific $\mathrm{CO}_{2}$ flux due to clear-ice facies formation $(\xi)$ of $0.012 \mathrm{~L} \mathrm{~m}^{-2} \mathrm{a}^{-1}$ at Glacier de Tsanfleuron. The precise distribution of this supply, however, will depend on spatial and temporal variability in rates of clear-facies ice formation across the glacier bed, which is currently unconstrained. Further, this rate of $\mathrm{CO}_{2}$ delivery may be supplemented by that generated by bacterially mediated oxidation of organic carbon within glacier ice, and in particular the debris-rich BZ (Sharp and others, 1999). This process may be at least partly responsible for the very high concentrations of $\mathrm{CO}_{2}$ recorded close to the bases of our cores (e.g. Fig. 8b), although other processes such as $\mathrm{CO}_{2}$ release during $\mathrm{CaCO}_{3}$ precipitation and pyrite oxidation (Fairchild and others, 1994b) may also be significant.

\section{ACKNOWLEDGEMENTS}

We thank R. Lorrain, A. Khazendar, R. Prytherch, L. Plewes and R. Cloke for fieldwork assistance, and L. Hill and G. Brown for laboratory assistance. The paper was significantly improved as a result of comments by R. LeB. Hooke, J. Kohler and an anonymous referee. This work was funded by NERC grant GR9/2026.

\section{REFERENCES}

Baker, R.W. 1978. The influence of ice-crystal size on creep. F. Glaciol., $21(85), 485-500$.

Barnes, P. and D. Tabor. 1966. Plastic flow and pressure melting in the deformation of ice I. Nature, 210(5039), 878-882.

Berner, W., P. Bucher, H. Oeschger and B. Stauffer. 1977. Analysis and interpretation of gas content and composition in natural ice. International Association of Hydrological Sciences Publication 118 (Symposium at Grenoble 1975Isotopes and Impurities in Snow and Ice), 272-284.

Brepson, R. 1979. Simulated glacier sliding over an obstacle. f. Glaciol., 23(89), 143-156.

Duval, P. 1977. The role of the water content on the creep rate of polycrystalline ice. International Association of Hydrological Sciences Publication 118 (Symposium at Grenoble 1975 - Isotopes and Impurities in Snow and Ice), 29-33.

Fairchild, I. J., L. Bradby, M. Sharp and J.-L. Tison. 1994. Hydrochemistry of carbonate terrains in alpine glacial settings. Earth Surf. Processes Landforms, 19(1), 33-54.

Hallet, B., R. Lorrain and R. Souchez. 1978. The composition of basal ice from a glacier sliding over limestones. Geol. Soc. Am. Bull., 89(2), 314-320.

Hambrey, M. J. 1975. The origin of foliation in glaciers: evidence from some Norwegian examples. f. Glaciol., 14(70), 181-185.

Hambrey, M. J. and A. G. Milnes. 1975. Boudinage in glacier ice - some

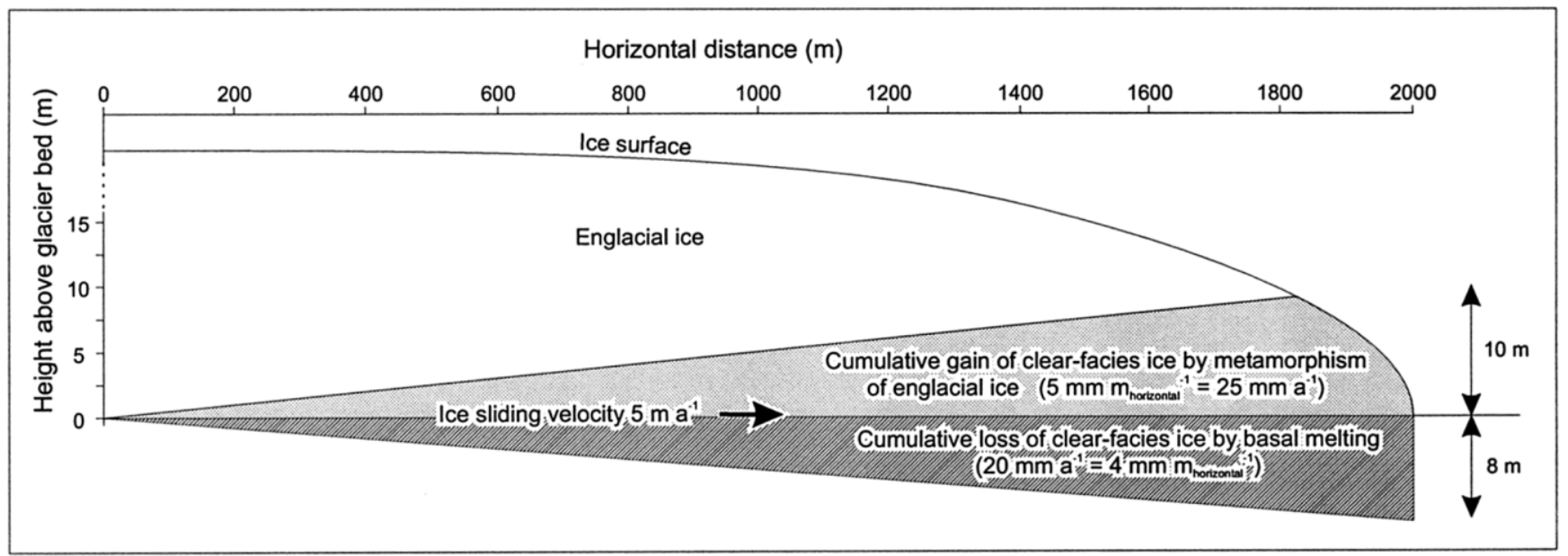

Fig. 9. Conceptual model of clear-facies ice formation at Glacier de Tsanfleuron used for $\mathrm{CO}_{2}$ flux calculations. Rates of clearfacies ice growth by englacial ice metamorphism, and loss by basal melting are described in the text. 
examples. 7. Glaciol., 14(72), 383-393.

Hambrey, M. J. and A. G. Milnes. 1977. Structural geology of an Alpine glacier (Griesgletscher, Valais, Switzerland). Eclogae Geol. Helv., 70(3), 667-684.

Herrmann, A., M. Lehrer and W. Stichler. 1981. Isotope input into runoff systems from melting snow covers. Nord. Hydrol., 12 (4-5), 309-318.

Hooke, R. LeB. and P. J. Hudleston. 1978. Origin of foliation in glaciers. $\mathcal{F}$. Glaciol., 20(83), 285-299.

Hooke, R. LeB., X. Q. Gao, T. H. Jacka and R. A. Souchez. 1988. Correspondence. Rheological contrast between Pleistocene and Holocene ice in Barnes Ice Cap, Baffin Island, N.W.T., Canada: a new interpretation. f. Glaciol., 34(118), 364-365.

Hubbard, B. P. 1992. Basal ice facies and their formation in the western Alps. (Ph.D. thesis, University of Cambridge.)

Hubbard, B. and A. Hubbard. 1998. Bedrock surface roughness and the distribution of subglacially precipitated carbonate deposits: implications for formation at Glacier de Tsanfleuron, Switzerland. Earth Surf. Processes Landforms, 23, 261-270.

Hubbard, B. and M. Sharp. 1989. Basal ice formation and deformation: a review. Prog. Phys. Geogr., 13(4), 529-558.

Hubbard, B. and M. Sharp. 1995. Basal ice facies and their formation in the western Alps. Arct. Alp. Res., 27(4), 301-310.

Jansson, P., J. Kohler and V. A. Pohjola. 1996. Characteristics of basal ice at Engabreen, northern Norway. Ann. Glaciol., 22, 114-120.

Jouzel, J. and R. A. Souchez. 1982. Melting-refreezing at the glacier sole and the isotopic composition of the ice. F. Glaciol., 28(98), 35-42.

Lawson, D. E. 1979. Sedimentological analysis of the western terminus region of the Matanuska Glacier, Alaska. CRREL Rep. 79-9.

Lehmann, M. and U. Siegenthaler. 1991. Equilibrium oxygen- and hydrogenisotope fractionation between ice and water. f. Glaciol., 37(125), 23-26.

Lemmens, M., R. Lorrain and J. Haren. 1983. Isotopic composition of ice and subglacially precipitated calcite in an Alpine area. Z. Gletscherkd. Glazialgeol., 18(2), 1982, 151-159.

Lliboutry, L. 1971. Permeability, brine content and temperature of temperate ice. 7. Glaciol., 10 (58), 15-29.

Lliboutry, L. 1976. Physical processes in temperate glaciers. f. Glaciol., 16 (74), 151-158.

Lliboutry, L. 1993. Internal melting and ice accretion at the bottom of temperate glaciers. 7. Glaciol., 39(131), 50-64.

Nakamura, T. and S. J. Jones. 1973. Mechanical properties of impure ice crystals. In Whalley, E., S. J. Jones and L.W. Gold, eds. Physics and chemistry of ice. Ottawa, Ont., Royal Society of Canada, 365-369.
Paterson, W. S. B. 1994. The physics of glaciers. Third edition. Oxford, etc., Elsevier. Pohjola, V. A. 1994. TV-video observations of englacial voids in Storglaciären, Sweden. 7. Glaciol., 40(135), 231-240.

Raymond, C. F. 1976. Some thermal effects of bubbles in temperate glacier ice. 7. Glaciol., 16(74), 159-171.

Raymond, C. F. and W. D. Harrison. 1975. Some observations on the behavior of the liquid and gas phases in temperate glacier ice. F. Glaciol., 14 (71), 213-233.

Raynaud, D. and B. Lebel. 1979. Total gas content and surface elevation of polar ice sheets. Nature, 281 (5729), 289-291.

Robin, G. de Q. 1976. Is the basal ice of a temperate glacier at the pressure melting point? f. Glaciol., 16(74), 183-196.

Russell-Head, D. S. and W. F. Budd. 1979. Ice-sheet flow properties derived from bore-hole shear measurements combined with ice-core studies. $\mathcal{F}$. Glaciol., 24(90), 117-130.

Sharp, M. J., J.-L. Tison and G. Fierens. 1990. Geochemistry of subglacial calcites: implications for the hydrology of the basal water film. Arct. Alp. Res., 22(2), 141-152.

Sharp, M., J. Parkes, B. Cragg, I. J. Fairchild, H. Lamb and M. Tranter. 1999. Widespread bacterial populations at glacier beds and their relationship to rock weathering and carbon cycling. Geology, 27(2), 107-110.

Souchez, R. A. and M. M. Lemmens. 1985. Subglacial carbonate deposition: an isotopic study of a present-day case. Palaeogeogr., Palaeoclimatol., Palaeoecol., 51 (1-4), 357-364.

Souchez, R., M. Lemmens, J.-L. Tison, R. Lorrain and L. Janssens. 1993. Reconstruction of basal boundary conditions at the Greenland ice sheet margin from gas composition in the ice. Earth Planet. Sci. Lett., 118(1-4), 327-333.

Theakstone, W. H. 1979. Observations within cavities at the bed of the glacier Østerdalsisen, Norway. F. Glaciol., 23 (89), 273-281.

Tison, J.-L. and R. D. Lorrain. 1987. A mechanism of basal ice-layer formation involving major ice-fabric changes. f. Glaciol., 33(113), 47-50.

Tison, J.-L., A. Bondesan, D. Ronveaux and M. Meneghel. 1997. Preliminary results from 60 shallow cores and from one $45 \mathrm{~m}$ deep marine ice core at Hells Gate Ice Shelf, Victoria Land, Antarctica. Terra Antartica Rep. 1, 19-24.

Tranter, M. and 9 others. 1997. Variability in the chemical composition of in situ subglacial meltwaters. Hydrol. Processes, 11(1), 59-78.

Vallon, M., J.-R. Petit and B. Fabre. 1976. Study of an ice core to the bedrock in the accumulation zone of an Alpine glacier. F. Glaciol., 17 (75), 13-28.

Vivian, R. and G. Bocquet. 1973. Subglacial cavitation phenomena under the Glacier d'Argentière, Mont Blanc, France. F. Glaciol., 12 (66), 439-451.

MS received 6 January 1999 and accepted in revised form 30 September 1999 